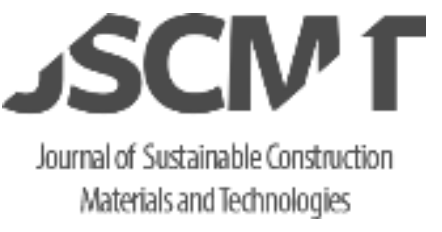

J Sustain. Construct. Mater. Technol. 3(3) (2018) 278-285 \begin{tabular}{c}
\hline \hline Journal of Sustainable \\
Construction Materials \\
and Technologies
\end{tabular}

www.eds.yildiz.edu.tr/jscmt

\title{
Effect of Fly Ash and Ground Granulated Blast Furnace Slag on The Strength of Concrete Pavement
}

\author{
Fatih Acıkök ${ }^{1, *}$, Orhan Canpolat ${ }^{1}$, Mücteba Uysal ${ }^{2}$, Yurdakul Aygörmez ${ }^{1}$, Furkan Şahin ${ }^{2}$ \\ ${ }^{l}$ Yildiz Technical University, Faculty Of Civil Engineering, Civil Engineering Department, Davutpasa Campus, \\ Istanbul, Turkey \\ ${ }^{2}$ Istanbul University, Engineering Faculty, Civil Engineering Department, Avcilar campus, Istanbul, Turkey
}

Manuscript Received August 10, 2018; Accepted October 25, 2018

\begin{abstract}
In this study, the effects of Fly Ash (FA) and Ground Granulated Furnace Slag (GGBFS) on design of concrete pavement are investigated. It has been observed how these mineral additives change the 7 days compressive strength and splitting tensile strength of the concrete pavement, the 28 days compressive strength, splitting tensile strength and bending strength of concrete pavement. The cement dosage is $350 \mathrm{~kg} / \mathrm{m}^{3}$ and water $/$ cement ratio is 0.42 . Three concrete mixture are produced. The first concrete mixture does not contain FA and GGBFS (reference concrete). The second concrete mixture contains 20 percent of the Portland cement is replaced with fly ash. Finally, the third concrete contains GGBFS displaced at the rate of $20 \%$ with cement. Three different molds are used in experiments. The first is cubic mold whose dimensions are $150 \mathrm{~mm}$. The second is cylinder mold whose diameter and length are $150 \mathrm{~mm}$ and $300 \mathrm{~mm}$, respectively. Finally, the third is beam mold whose dimension of cross-section and length are $150 \mathrm{~mm} \times 150 \mathrm{~mm}$, and $550 \mathrm{~mm}$, respectively. The study was carried out according to the Specifications of General Directorate of Turkish Highways (GDTH) (2016).
\end{abstract}

Keywords: Concrete, Concrete Pavement, Fly Ash, Slag, Compressive Strength, Splitting Tensile Strength, Bending Strength

\section{Introduction}

Concrete pavement (rigid superstructure) is a road superstructure made with concrete material. Also, they distribute the wheel and axle loads to the base [1]. Concrete pavement (rigid superstructure) and asphalt pavement (flexible superstructure) are used alternatives to each other in a lot of countries in the world. Also, the right choice of the road type to be built depends on many factors as the resources and budget of the country, the traffic load thought to pass the road, ground properties etc.

Concrete pavements according to asphalt pavements are relatively insufficient in number and length in Turkey. There are a few concrete roads built by the General Directorate of Turkish Highways (GDTH) for testing. "Technical Specifications of Concrete Pavement" which contains construction techniques and applications of concrete roads was published by the General Directorate of Turkish Highways in 2016.

Micron-sized ash particles are formed a result of the combustion of the powdered coal during the production of

\footnotetext{
* Corresponding author.

E-mail address:f1314035@std.yildiz.edu.tr (Fatih Acıkök)
}

https://doi.org/10.29187/jscmt.2018.31 
electricity in thermal power plants. Ash particles which are carried by the flue gasses are prevented from getting out of the atmosphere by the help of electron filters. Those ashes are an industrial waste called fly ash (FA) [2, 3]. Fly ashes occur as a by-product in ground granulated coal power plants. They are also stored as waste away from power plants. Specific gravity is between 1.90 and $2.8 \mathrm{~g} / \mathrm{cm} 3$. Its color is gray or light brown. Size of grain is under $35 \mu$. Surface area is between 300 and $500 \mathrm{~m}^{2} / \mathrm{kg}$.

Fly ash effects a lot of properties of fresh and hardened concrete and it effects durability of hardened concrete. Unlike other pozzolans, fly ash reduces the water requirement of the mixture and makes it easier to workability. However, the amount, fineness and carbon content of ash are an impressive factor [4].

Fly ash reduces early strength and hydration heat but increases ultimate strength and extends initial setting time. It also increases the resistance of concrete to alkali silica and sulfate attack reactions. Fly ash reduces the cost of concrete when substituted with cement.

The ground granulated blast furnace slag (GGBFS), which is produced as a by-product in iron and steel plants, has a great influence on the fresh and hardened concrete such as fly ash. It reduces the water requirement and makes easier workability of fresh concrete. It reduces hydration heat and extends initial setting time. It improves durability properties of hardened concrete and reduces permeability of hardened concrete. It reduces early strength of concrete but increases ultimate strength of concrete.

Blaine fineness of GGBFS is between 400 and $700 \mathrm{~kg} / \mathrm{m}^{2}$. Specific gravity is between 2.85 and $2.95 \mathrm{~g} / \mathrm{cm}^{3}$.

Strength is the ability of concrete of a certain age to resist stresses or forces [5]. Tensile strength of concrete is approximately $10 \%$ of compressive strength. Bending strength is about $15-20 \%$ of the compressive strength.

Positive and negative factors affect compressive strength of concrete. Those factors are aggregate type and its gradation, amount of cement and its type, rate of water/cement, curing, usage of chemical and mineral additive, production method of fresh concrete, mixing time, mixing stages, and placement methods of concrete.

Strength of concrete is not characteristic. Results which is obtained a certain concrete mix are linked to the geometry and size of the sample, preparation of concrete, and loading method [6].

In this study, the effects of FA and GGBFS on the compressive, splitting tensile, and bending strength of concrete used in concrete pavement are investigated. It is also intended to provide an archive for future in Turkey for concrete pavements.

\section{Experimental Study}

\subsection{Used Materials}

\section{a) Aggregate}

Limestone aggregate is used in concrete mixtures. Supplied in 3 groups $(0-5 \mathrm{~mm}, 5-13 \mathrm{~mm}, 13-25 \mathrm{~mm})$ from Ankara Hisarlikaya Quarry. The aggregates conform to the standard TS 706 EN 12620 (Concrete Aggregates).

\section{Dmax:22,4mm Gradation Curve}

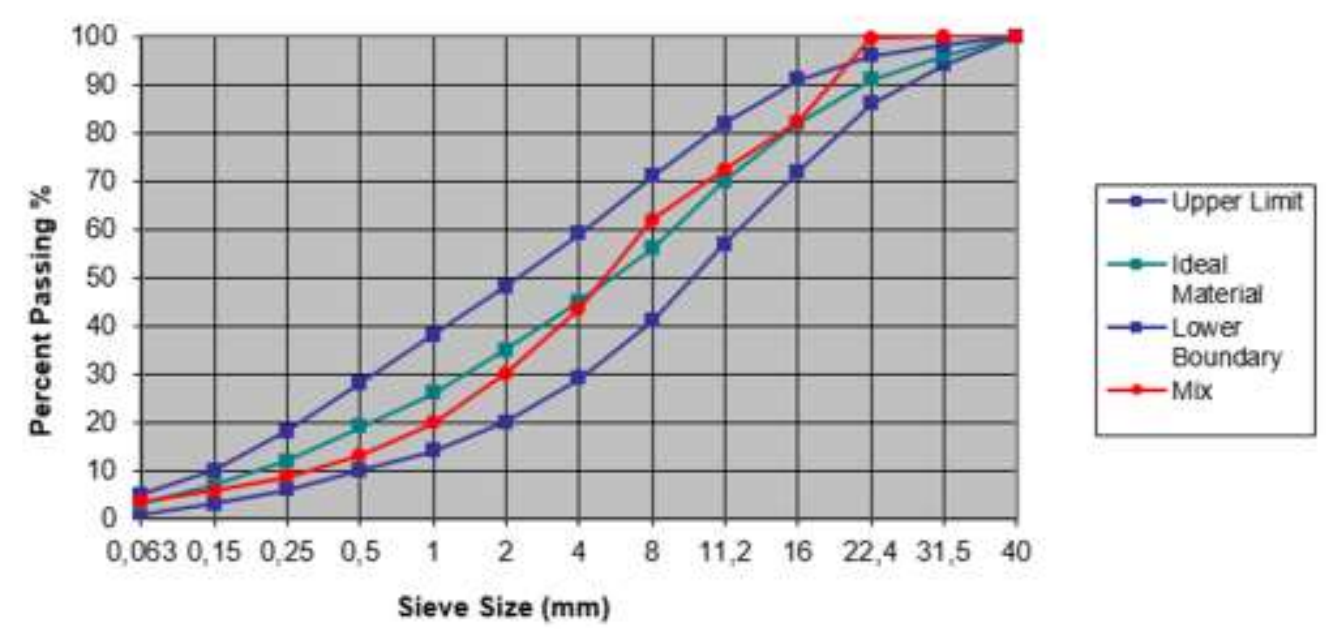

Fig. 1. Aggregate Gradation Curve 
Table 1. TS 802 (June 2009) Specification Values

\begin{tabular}{|c|c|c|c|c|}
\hline \multirow{2}{*}{$\begin{array}{c}\text { Sieve } \\
(\mathrm{mm})\end{array}$} & \multicolumn{3}{|c|}{ Passing Through From Sieve (\%) } & \multirow{2}{*}{} \\
\cline { 2 - 4 } & Min. & Mean & Max. & Mix $(\%)$ \\
\hline 0,063 & 1 & 3 & 5 & 3,4 \\
\hline 0,15 & 3 & 7 & 10 & 6 \\
\hline 0,25 & 6 & 12 & 18 & 9 \\
\hline 0,5 & 10 & 19 & 28 & 13 \\
\hline 1 & 14 & 26 & 38 & 20 \\
\hline 2 & 20 & 35 & 48 & 30 \\
\hline 4 & 29 & 45 & 59 & 43 \\
\hline 8 & 41 & 56 & 71 & 62 \\
\hline 11,2 & 57 & 70 & 82 & 72 \\
\hline 16 & 72 & 82 & 91 & 82 \\
\hline 22,4 & 86 & 91 & 96 & 100 \\
\hline 31,5 & 94 & 96 & 98 & 100 \\
\hline 40 & 100 & 100 & 100 & 100 \\
\hline & & & & \\
\hline
\end{tabular}

Table 2. Selected Mixtures Percentages

\begin{tabular}{|c|c|c|c|c|}
\cline { 2 - 4 } \multicolumn{1}{c|}{} & $\mathbf{\% ~ 4 9}$ & $\mathbf{\% ~ 2 1}$ & $\mathbf{\% ~ 3 0}$ & \multicolumn{1}{c|}{} \\
\hline \multirow{2}{*}{$\begin{array}{c}\text { Sieve } \\
(\mathrm{mm})\end{array}$} & $0-5 \mathrm{~mm}$ & $5-13 \mathrm{~mm}$ & $13-25 \mathrm{~mm}$ & \\
\cline { 2 - 5 } & \multicolumn{3}{|c|}{$\%$ Passing } & Mix \\
\hline 40 & 100,0 & 100,0 & 100,0 & 100 \\
\hline 31,5 & 100,0 & 100,0 & 100,0 & 100 \\
\hline 22,4 & 100,0 & 100,0 & 98,4 & 100 \\
\hline 16 & 100,0 & 100,0 & 41,0 & 82 \\
\hline 11,2 & 100,0 & 97,6 & 9,2 & 72 \\
\hline 8 & 100,0 & 58,8 & 1,5 & 62 \\
\hline 4 & 86,9 & 2,3 & 1,3 & 43 \\
\hline 2 & 59,7 & 1,3 & 1,3 & 30 \\
\hline 1 & 39,1 & 1,3 & 1,3 & 20 \\
\hline 0,5 & 25,5 & 1,2 & 1,3 & 13 \\
\hline 0,25 & 16,2 & 1,2 & 1,3 & 9 \\
\hline 0,15 & 10,3 & 1,2 & 1,3 & 6 \\
\hline 0,063 & 6,0 & 1,1 & 0,9 & 3 \\
\hline
\end{tabular}

\section{b) Cement}

Cement (Portland) belongs to Limak Cement Factory. The cement conform to the standard TS 197-1.

Table 3. Chemical Properties of Cement

\begin{tabular}{|c|c|c|c|c|c|c|c|c|c|}
\hline $\mathrm{SiO}_{2}$ & $\mathrm{Al}_{2} \mathrm{O}_{3}$ & $\mathrm{Fe}_{2} \mathrm{O}_{3}$ & $\mathrm{CaO}$ & $\mathrm{MgO}$ & $\mathrm{Na}_{2} \mathrm{O}$ & $\mathrm{K}_{2} \mathrm{O}$ & $\mathrm{C}_{3} \mathrm{~S}$ & $\mathrm{C}_{3} \mathrm{~A}$ & $\mathrm{C}_{4} \mathrm{AF}$ \\
\hline $\begin{array}{c}\%, 16 \\
18,16\end{array}$ & $\% 4,62$ & $\% 2,95$ & $\begin{array}{c}\% \\
64,15\end{array}$ & $\% 1,98$ & $\% 0,11$ & $\% 0,61$ & $\begin{array}{c}\% \\
80,30\end{array}$ & $\% 7,25$ & $\% 8,98$ \\
\hline
\end{tabular}


Table 4. Chemical Properties of Cement

\begin{tabular}{|c|c|c|c|c|c|}
\hline Limestone & $\begin{array}{c}\text { Loss on } \\
\text { Ignition }\end{array}$ & $\begin{array}{c}\text { Insoluble } \\
\text { Residue }\end{array}$ & $\begin{array}{c}\text { Sulfate } \\
\text { Content } \\
\left(\text { as } \mathrm{SO}_{3}\right)\end{array}$ & $\begin{array}{c}\text { Chloride } \\
\text { Content }\end{array}$ & Pozzolanicity \\
\hline$\% 4,76$ & $\% 3,23$ & $\% 0,44$ & $\% 2,47$ & $\% 0,01$ & Appropriate \\
\hline
\end{tabular}

Table 5. Mechanical and Physical Properties of Cement

\begin{tabular}{|c|c|c|c|c|c|c|}
\hline & \multicolumn{2}{|c|}{ Initial Setting Time (minute) } & \multicolumn{3}{c|}{ Expansion (mm) } \\
\hline $\begin{array}{c}\text { Strength } \\
\text { Class }\end{array}$ & $\begin{array}{c}\text { Desired } \\
\text { Value }\end{array}$ & $\begin{array}{c}\text { Test } \\
\text { Result }\end{array}$ & & $\begin{array}{c}\text { Desired } \\
\text { Value }\end{array}$ & $\begin{array}{c}\text { Test } \\
\text { Result }\end{array}$ & \\
\hline $42,5 \mathrm{R}$ & $\geq 60$ & 180 & Appropriate & $\leq 10$ & 0,5 & Appropriate \\
\hline
\end{tabular}

c) Fly Ash

F class fly ash used in mixtures produced by AKSA Akrilik Kimya San. A.Ş. The fly ash conform to the standard TS EN 450-1.

Table 6. Properties of FA

\begin{tabular}{|c|c|c|c|c|c|c|c|c|c|c|}
\hline $\begin{array}{c}\text { Loss on } \\
\text { Ignition }\end{array}$ & $\mathrm{SiO}_{2}$ & $\begin{array}{c}\text { Chloride } \\
\left(\mathrm{Cl}^{-}\right)\end{array}$ & $\mathrm{Fe}_{2} \mathrm{O}_{3}$ & $\mathrm{Al}_{2} \mathrm{O}_{3}$ & $\mathrm{MgO}$ & $\mathrm{SO}_{3}$ & $\begin{array}{c}\mathrm{CaO} \\
\text { (free) }\end{array}$ & $\begin{array}{c}\mathrm{CaO} \\
\text { (reactive) }\end{array}$ & $\mathrm{Na}_{2} \mathrm{O}$ & $\mathrm{K}_{2} \mathrm{O}$ \\
\hline$\% 3,41$ & $\begin{array}{c}\% \\
54,03\end{array}$ & $\begin{array}{c}\% \\
0,0050\end{array}$ & $\begin{array}{c}\% \\
11,81\end{array}$ & $\% 15,47$ & $\% 3,73$ & $\% 0,58$ & $\% 1,55$ & $\% 0,065$ & $\% 2,34$ & $\begin{array}{c}\% \\
1,89\end{array}$ \\
\hline
\end{tabular}

d) Ground Granulated Blast Furnace Slag

Ground Granulated Blast Furnace Slag used in mixtures produced by Bolu Cement Factory. The GGBFS conform to the standards TS EN 15167-1 and TS EN 15167-2.

Table 7. Properties of GGBFS

\begin{tabular}{|c|c|c|c|c|c|c|c|c|}
\hline $\begin{array}{c}\text { Loss on } \\
\text { Ignition }\end{array}$ & $\mathrm{MgO}$ & $\mathrm{SO}_{3}$ & $\left(\mathrm{Na}_{2} \mathrm{O}\right)$ & $\left(\mathrm{K}_{2} \mathrm{O}\right)$ & $\begin{array}{c}\text { Sulphit } \\
\left(\mathrm{S}^{=}\right)\end{array}$ & $\begin{array}{c}\text { Total } \\
\text { Chloride } \\
\left(\mathrm{Cl}^{-}\right)\end{array}$ & $\begin{array}{c}\text { Moisture } \\
\text { Content Of } \\
\text { Alkalis } \\
\left(\mathrm{Na}_{2} \mathrm{O}\right. \\
\text { Equivalent })\end{array}$ \\
\hline$\% 0,01$ & $\% 6,16$ & $\% 0,22$ & $\% 0,90$ & $\% 0,53$ & $\% 0,67$ & $\% 0,0177$ & $\% 0,05$ & $\% 1,24$ \\
\hline
\end{tabular}




\subsection{Mixing Information and Specimens}

Water/cement ratio of mixture 0.42 . Cement dosage is $350 \mathrm{~kg} / \mathrm{m} 3$ and C30/37 strength class determined.

Mold sizes for Reference concrete mix, \% 20 FA concrete mix and \%20 GBFS concrete mix;

-3 pieces of $150 \times 150 \times 150 \mathrm{~mm}$ cube mold for 7 and 28 days compressive strength

-3 pieces of $150 \mathrm{~mm}$ diameter $-300 \mathrm{~mm}$ length cylinder mold for 7 and 28 days splitting tensile strength

- 3 pieces of $150 \times 150 \times 550 \mathrm{~mm}$ beam mold for 28 days bending strength

Concrete mix made and fresh concrete was placed in the molds in accordance with the standards. Temperature of reference concrete mix measured approximately $23^{\circ} \mathrm{C}$. The temperature of $\% 20$ FA concrete and $\% 20$ GGBFS concrete mixes measured $21^{\circ} \mathrm{C}$. Samples in the mold at a temperature of $20 \pm 5{ }^{\circ} \mathrm{C}$, relative humidity of $\% 95$ in the curing room was kept for 24 hours. Then the samples were then removed from the mold sand placed in the curing pool at $20 \pm 2{ }^{\circ} \mathrm{C}$.

Table 8. Slump and Air Content Values of Fresh Concrete Mixtures

\begin{tabular}{|c|c|c|c|}
\hline & Reference Mixture & $\begin{array}{c}\text { Mixture With \% 20 } \\
\text { FA }\end{array}$ & $\begin{array}{c}\text { Mixture With \% 20 } \\
\text { GBFS }\end{array}$ \\
\hline Slump (mm) & 2 & 3 & 2 \\
\hline Air Content (\%) & 5,4 & 5,7 & 4,5 \\
\hline
\end{tabular}

For compressive strength test $0,6 \mathrm{MPa} / \mathrm{s}(\mathrm{N} / \mathrm{mm} 2 . \mathrm{s})$, for splitting tensile strength test and two-point bending test $0,05 \mathrm{MPa} / \mathrm{s}(\mathrm{N} / \mathrm{mm} 2 . \mathrm{s})$ loading rate applied.

\section{Test Results}

Table 9. 7-Days Compressive Strength

\begin{tabular}{|c|c|c|c|c|c|}
\hline $\begin{array}{c}\text { Reference } \\
\text { Mixture } \\
\text { (MPa) }\end{array}$ & $\begin{array}{c}\text { Reference } \\
\text { Mixture } \\
\text { Average } \\
\\
\text { (MPa) }\end{array}$ & $\begin{array}{c}\text { Mixture } \\
\text { With \% } 20 \\
\text { FA } \\
\text { (MPa) }\end{array}$ & $\begin{array}{c}\text { Mixture } \\
\text { With \% 20 } \\
\text { FA Avarage } \\
\text { (MPa) }\end{array}$ & $\begin{array}{c}\text { Mixture } \\
\text { With \% 20 } \\
\text { GBFS } \\
\text { (MPa) }\end{array}$ & $\begin{array}{c}\text { Mixture With } \\
\text { \% 20 GGBFS } \\
\text { Avarage } \\
\text { (MPa) }\end{array}$ \\
\hline 44,34 & \multirow{3}{*}{42,10} & 35,54 & \multirow{3}{*}{35,78} & 38,55 & \multirow{3}{*}{38,14} \\
\hline 41,52 & & 36,34 & & 38,41 & \\
\hline 40,44 & & 35,46 & & 37,47 & \\
\hline
\end{tabular}


Table 10. 7-Days Splitting Tensile Strength Results

\begin{tabular}{|c|c|c|c|c|c|}
\hline $\begin{array}{c}\text { Reference } \\
\text { Mixture } \\
\text { (MPa) }\end{array}$ & $\begin{array}{c}\text { Reference } \\
\text { Mixture } \\
\text { Average } \\
\text { (MPa) }\end{array}$ & $\begin{array}{c}\text { Mixture } \\
\text { With \% } 20 \\
\text { FA } \\
\text { (MPa) }\end{array}$ & $\begin{array}{c}\text { Mixture } \\
\text { With \% } 20 \\
\text { FA Avarage } \\
\text { (MPa) }\end{array}$ & $\begin{array}{c}\text { Mixture } \\
\text { With \% } 20 \\
\text { GBFS } \\
\text { (MPa) }\end{array}$ & $\begin{array}{c}\text { Mixture With } \\
\text { \% } 20 \text { GGBFS } \\
\text { Avarage } \\
\text { (MPa) }\end{array}$ \\
\hline 3,91 & \multirow{3}{*}{4,08} & 3,36 & \multirow{3}{*}{3,58} & 3,61 & \multirow{3}{*}{$\mathbf{3 , 8 1}$} \\
\hline 4,23 & & 3,72 & & 3,82 & \\
\hline 4,11 & & 3,66 & & 4,02 & \\
\hline
\end{tabular}

Table 11. 28-Days Compressive Strength Results

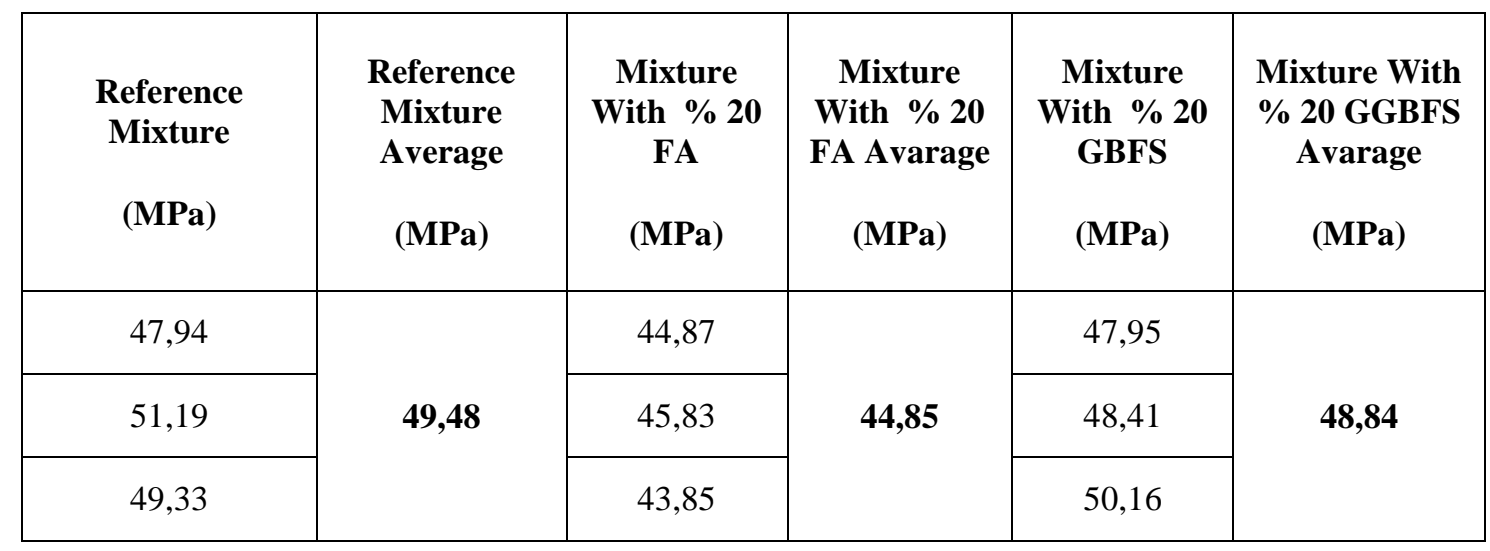

Table 12. 28-Days Splitting Tensile Strength Results

\begin{tabular}{|c|c|c|c|c|c|}
\hline $\begin{array}{c}\text { Reference } \\
\text { Mixture } \\
\text { (MPa) }\end{array}$ & $\begin{array}{c}\text { Reference } \\
\text { Mixture } \\
\text { Average } \\
\text { (MPa) }\end{array}$ & $\begin{array}{c}\text { Mixture } \\
\text { With \% } 20 \\
\text { FA } \\
\text { (MPa) }\end{array}$ & $\begin{array}{c}\text { Mixture } \\
\text { With \% } 20 \\
\text { FA Avarage } \\
\text { (MPa) }\end{array}$ & $\begin{array}{c}\text { Mixture } \\
\text { With \% } 20 \\
\text { GBFS } \\
\text { (MPa) }\end{array}$ & $\begin{array}{c}\text { Mixture With } \\
\text { \% } 20 \text { GGBFS } \\
\text { Avarage } \\
\text { (MPa) }\end{array}$ \\
\hline 4,21 & \multirow{3}{*}{4,30} & 3,92 & \multirow{3}{*}{3,87} & 4,41 & \multirow{3}{*}{4,26} \\
\hline 4,31 & & 4,03 & & 4,45 & \\
\hline 4,38 & & 3,68 & & 3,93 & \\
\hline
\end{tabular}


Table 13. 28-Days Bending Strength Results

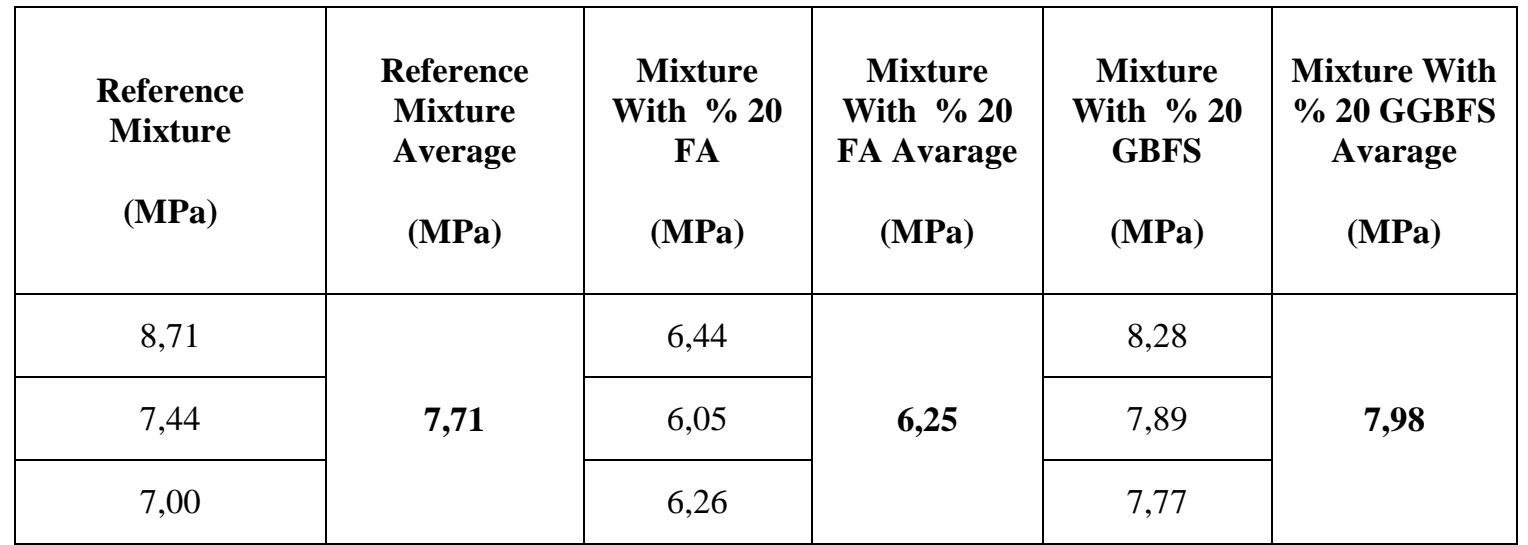

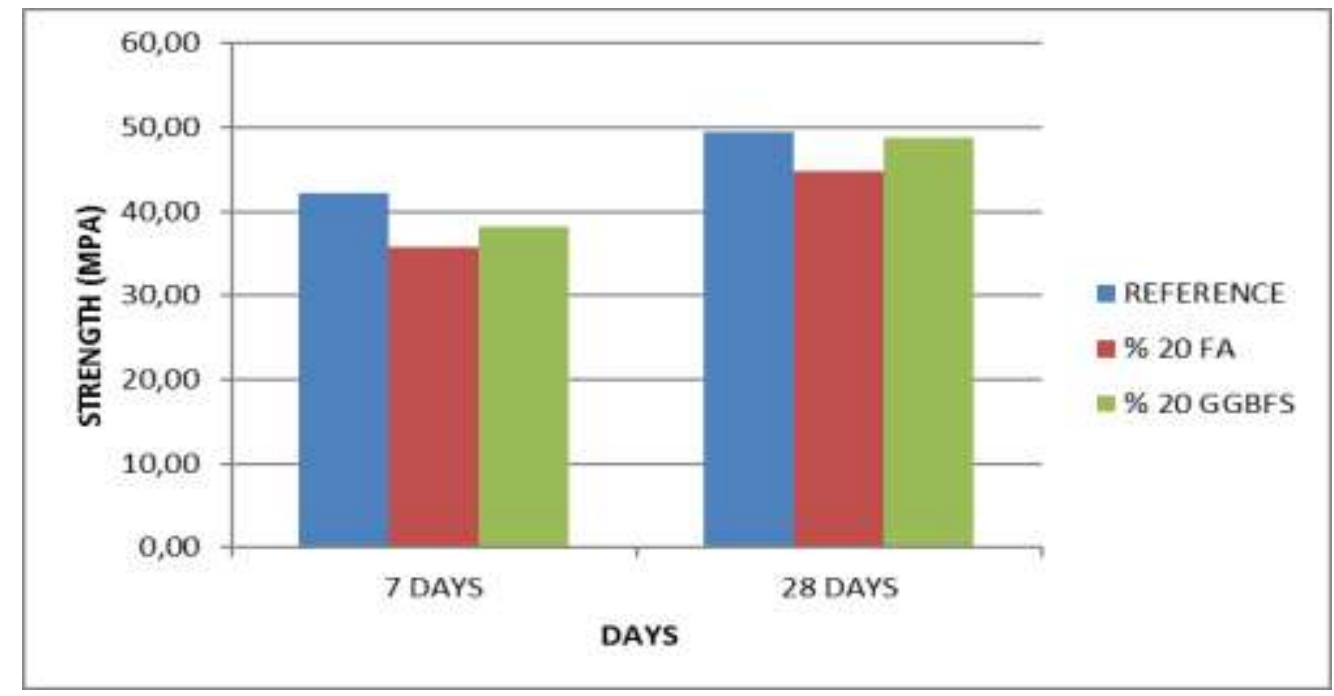

Fig. 2. Compressive Strength

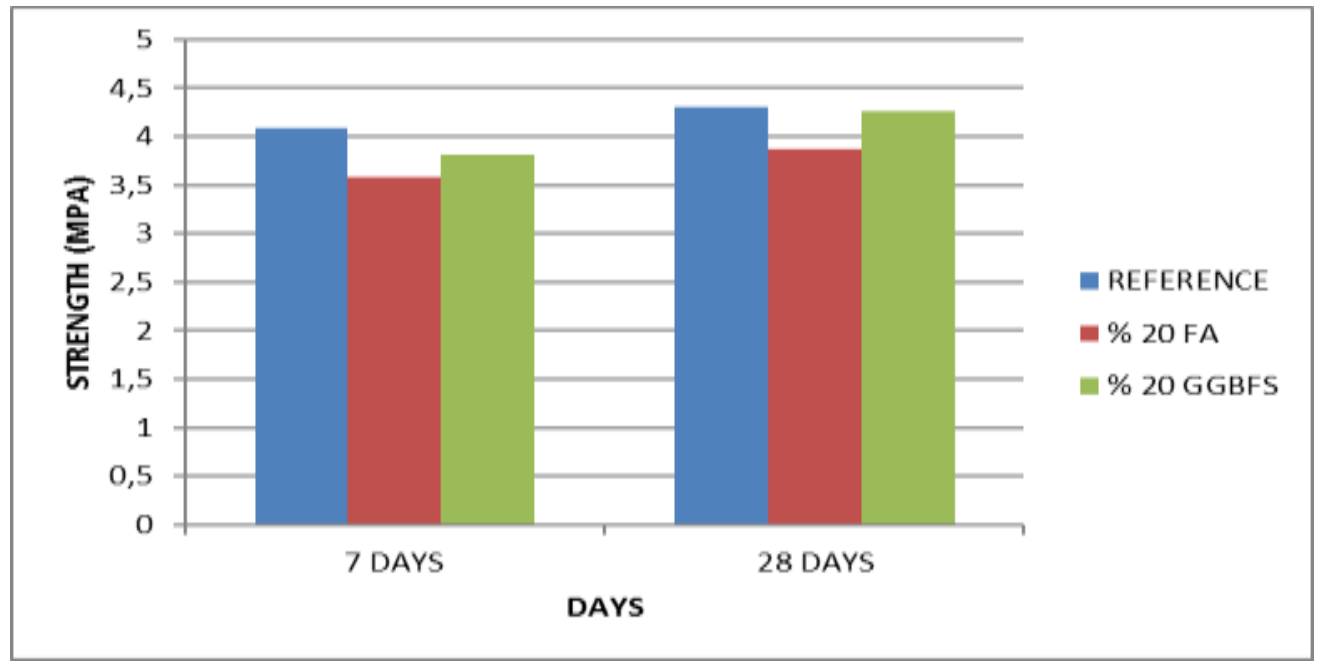

Fig. 3. Splitting Tensile Strength 


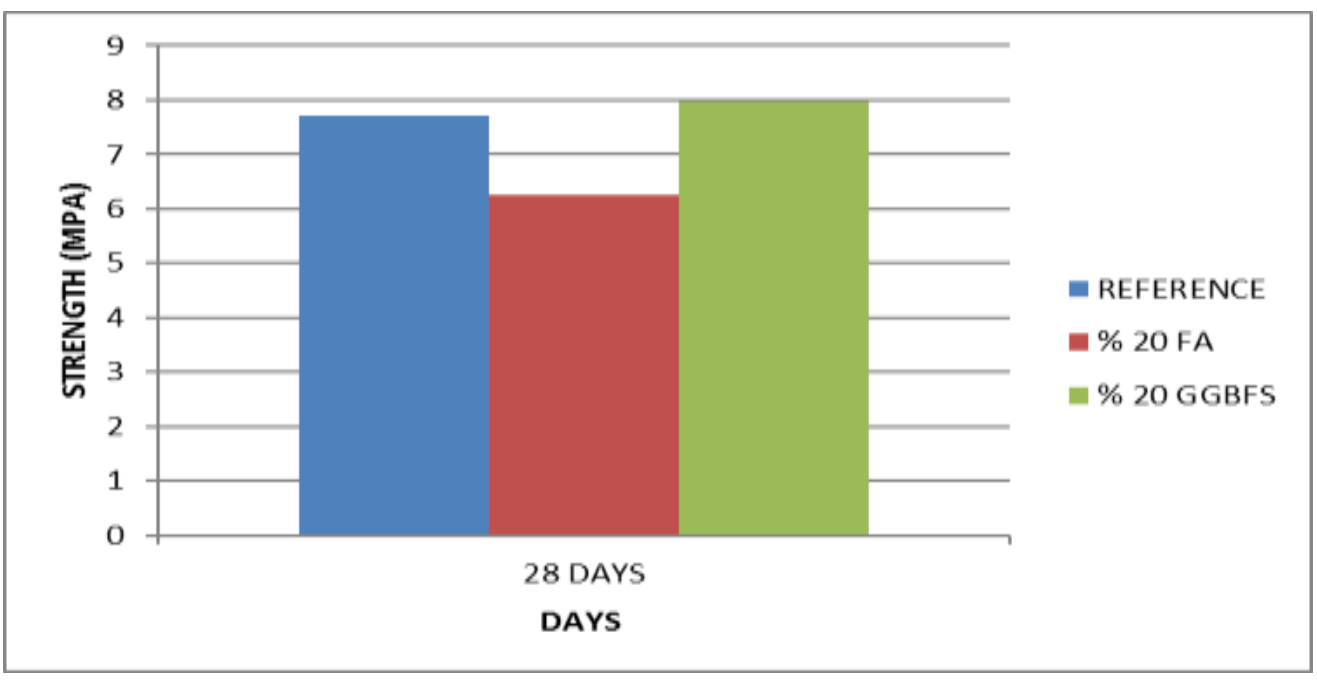

Fig. 4. Bending Strength

\section{Results and Discussions}

All 28-day strength values of all three mixtures increased according to 7-days strength values. The reference mixture has the highest value for all 7 and 28 days strengths except 28-day bending strength. 28 days compressive and splitting tensile strength of GGBFS mixture almost reached the strength of Reference mixture. 28-days bending strength of the mixture with GGBFS even exceeded the bending strength of Reference mixture.

The 7 and 28 days all strength values of the FA mixture remained below the strength values of the other mixtures.

7-days strength values of GGBFS mixture are greater than 7-days strengths of FA mixtures. In terms of opening concrete pavements to early traffic, ground granulated blast furnace slag can be said to be a small advantage compared to fly ash.

Mineral admixtures such as fly ash and slag can provide great advantages for concrete pavements to different climate zones. Sources in the literature also show that 56 days and 90 days strengths of mixtures with the slag and fly ash reach the values of reference mixtures. In the long term, mixtures containing mineral additives increase the strength to the desired level.

Mineral admixtures provide the economy in concrete provide that they are used in appropriate proportion sand quality. It also reduces the permeability in concrete and positively affects durability.

\section{References}

1. Karayolları Genel Müdürlüğü Beton Yol Kaplamaları Teknik Şartnamesi,(2016),P.1

2. Tokyay, M., Erdoğdu, K., (1998). ' Türkiye Termik Santrallerinden Elde Edilen Uçucu Küllerin Karakterizasyonu', TÇMB, Ankara

3. Aruntaş, H., (2006). 'Uçucu Küllerin İnşaat Sektöründe Kullanım Potansiyeli', Gazi Univ. Müh. Mim. Fak.Der. Cilt 21, No 1, 193-203, Ankara

4. Özturan T., '’Beton Üretiminde Uçucu Kül Kullanımının İrdelenmesi', BogaziçiUniv.

5. Taylor, P.C.; S.H. Kosmatka; G.F. Voigt; (2006). "Integrated Materials and Construction Practices for Concrete Pavements", A State-of-the-Practice Manual. Ames, IA: National Concrete Pavement Technology Center, Iowa StateUniversity.

6. Carrasquillo, (1994).”Concrete Strength Testing. Significance Of Tests and Properties of Concrete Making Materials" 